\title{
IMPLEMENTASI BOTTOM AIR DECK DAN EXPAND PATTERN SECARA TERINTEGRASI DALAM RANGKA OPTIMALISASI PENGGUNAAN BAHAN PELEDAK DI PIT SOUTH PINANG PT. KALTIM PRIMA COAL
}

Masda Rohal Sadiq

Departemen Drill \& Blast, PT. Kaltim Prima Coal

Artikel masuk : 17-04-2021 , Artikel diterima : 17-04-2021

Kata kunci :

Bottom Air Deck, Expand Pattern, Powder Factor, Kuz-ram, Scale Depth Of Burrial

\begin{abstract}
ABSTRAK
Harga jual batubara yang terus melemah, membuat PT. Kaltim Prima Coal menekan berbagai komponen pengeluaran, yaitu efisiensi penggunaan bahan peledak. Seiring perkembangan teknologi, beberapa metode dikembangkan tanpa menurunkan kualitas hasil peledakan. Metode tersebut dilakukan dengan cara sebagai berikut : 1.Implementasi Bottom Air Deck pada Lubang Ledak. Rongga udara yang ada akan menyebabkan energi hasil peledakan lebih merata ke sekitar lubang ledak dan menciptakan fragmentasi peledakan yang lebih seragam. Implementasi ini diterapkan pada kedalaman lubang 7,5-11 m, dengan efisiensi bahan peledak $15-17 \%$ per lubang. 2.Trial Expand Pattern menggunakan Analisa Kuz-Ram dan Scale Depth Of Burrial (S.D.O.B) untuk memprediksi dan mengontrol fragmentasi batuan hasil peledakan yang dapat mengoptimalkan Powder Factor 5$11 \%$. Setelah melakukan 2 metode selama bulan Januari-September 2020, efisiensi penggunaan bahan peledak sebesar $8,6 \%$. Penghematan bahan peledak tersebut setara dengan penghematan biaya operasional sebesar $\$ 84,888$ (Rp.1.2 Milyar). Di sisi lain, aktual produktifitas alat gali-muat Libherr S420 dan Hitachi S321 yang beroperasi di Pit South Pinang, masing- masing masih produktif di angka 5,3\% dan $4,7 \%$ (Aktual Prodt'y S420 $=2,106 \mathrm{bcm} / \mathrm{hr}$ terhadap budget $=2,000 \mathrm{bcm} / \mathrm{hr}$ dan Aktual Prodt'y S321 $=1,314 \mathrm{bcm} / \mathrm{hr}$ terhadap budget $=1,255 \mathrm{bcm} / \mathrm{hr}$ )
\end{abstract}

*Penulis Koresponden: masda.sadiq@kpc.co.id

Doi : https://doi.org/10.36986/impj.v3i1.39 


\section{ABSTRACT}

The selling price of coal continues to weaken, making PT. Kaltim Prima Coal suppresses various components of expenditure, namely the efficient use of explosives. Along with the development of technology, several methods were developed without reducing the quality of the blasting product. The method is carried out in the following way: 1. Implementation of Bottom Air Deck on the Explosion Hole. The air cavity that is present will cause the energy of the detonation to be more evenly distributed around the blast hole and create a more uniform fragmentation of the detonation. This implementation is applied to a hole depth of 7.5-11 m, with an explosive efficiency of $15-17 \%$ per hole. 2. Trial Expand Pattern using Kuz-Ram Analysis and

\section{PENDAHULUAN}

PT Kaltim Prima Coal (KPC) adalah perusahaan tambang batubara terbesar yang ada di Indonesia, berlokasi di Kota Sangatta, Kalimantan Timur. PT KPC menerapkan metode penambangan terbuka (surface mining) dan menargetkan produksi batubara di tahun 2020 sebanyak 64.3 juta ton. Dengan nisbah kupas (Stripping Ratio) 8.5:1, maka jumlah tanah penutup yang harus dipindahkan adalah sebanyak 546 juta bcm.

Banyaknya jumlah tanah penutup yang harus dipindahkan membuat proses pengupasan tanah penutup menjadi salah satu hal yang sangat krusial untuk mencapai target produksi yang telah ditetapkan. Dalam proses pemindahan tanah penutup, kegiatan peledakan memegang peranan
Scale Depth Of Burrial (S.D.O.B) to predict and control rock fragmentation resulting from blasting which can optimize Powder Factor 5-11\%. After carrying out 2 methods during January-September 2020, the efficiency of using explosives was $8.6 \%$. This savings in explosives was equivalent to an operating cost savings of $\$ 84,888$ (Rp. 1.2 billion). On the other hand, the actual productivity of the Libherr S420 and Hitachi S321 digging tools operating in the South Pinang Pit, respectively, is still productive at $5.3 \%$ and $4.7 \%$ (Actual Prodt'y S420 $=2.106 \mathrm{bcm} / \mathrm{hr}$ against budget $=2,000 \mathrm{bcm} / \mathrm{hr}$ and Actual Prodt'y S321 = $1,314 \mathrm{bcm} / \mathrm{hr}$ against budget $=1,255 \mathrm{bcm} / \mathrm{hr}$ )Keywords : Bottom Air Deck, Expand Pattern, Powder Factor, Kuzram, Scale Depth Of Burrial

penting karena sebagian besar proses pemindahannya memerlukan peledakan.

Salah satu wilayah operasional PT KPC menjadi fokus penelitian saat ini adalah Pit South Pinang panel 3 \& 4 yang secara mandiri di operasikan oleh Departemen Jupiter. Berdasarkan budget di tahun 2020, ditetapkan rencana pengupasan tanah penutup adalah sebesar 16,710.015 Bcm dengan rasio penggunaan bahan peledak (Powder Factor) sebesar $0.220 \mathrm{Kg} / \mathrm{Bcm}$, sehingga di butuhkan bahan peledak sebanyak 3,676,203 kg. PT KPC mengeluarkan biaya yang sangat besar untuk menyediakan bahan peledak curah ini sehingga hasil akhir dari peledakan perlu dioptimalkan, salah satunya dengan memanfaatkan perkembangan teknologi terkini dalam proses peledakan
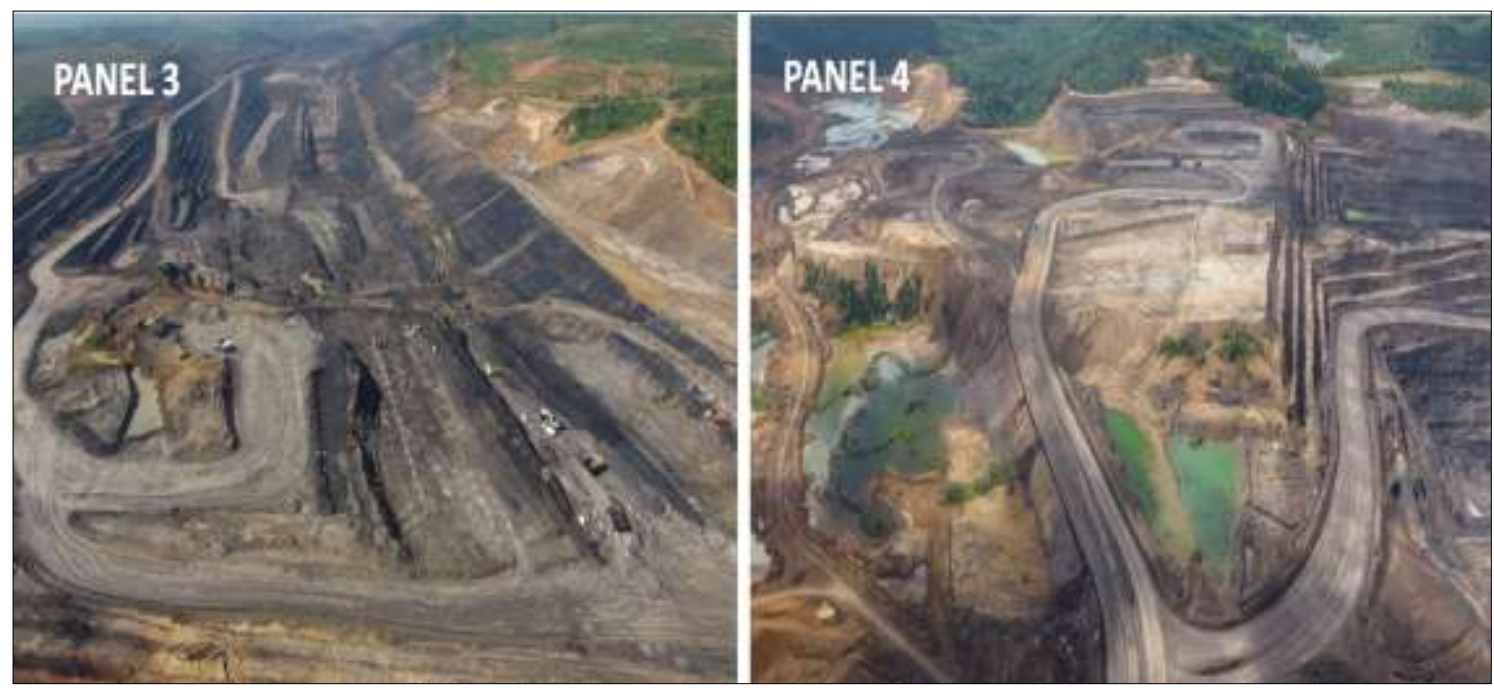

Gambar 1. Panel 3 \& 4 Pit South Pinang (Departement Jupiter)

Selain rencana anggaran biaya bahan peledak yang cukup besar, terdapat beberapa latar belakang lain sebagai dasar untuk melakukan proyek penelitian ini adalah sebagai berikut : 
- Melemahnya Harga Jual Batu Bara (HBA)

Berdasarkan sumber informasi dari Kementrian ESDM, terlihat pergerakan harga jual batubara (HBA) yang terus melemah dari tahun ke tahun. Dari grafik di bawah terlihat jelas HBA di awal tahun 2019 berada di level $\$ 92.41 /$ ton sedangkan di awal tahun 2020 melemah di level
$\$ 65.93$ / ton dan terus merosot tajam di bulan Juli 2020 di level \$ 52.16/ ton imbas dari meluasnya pandemi wabah Covid-19. Dengan kata lain telah terjadi pelemahan harga sebesar kurang lebih $44 \%$ selama 1.5 tahun belakangan ini.

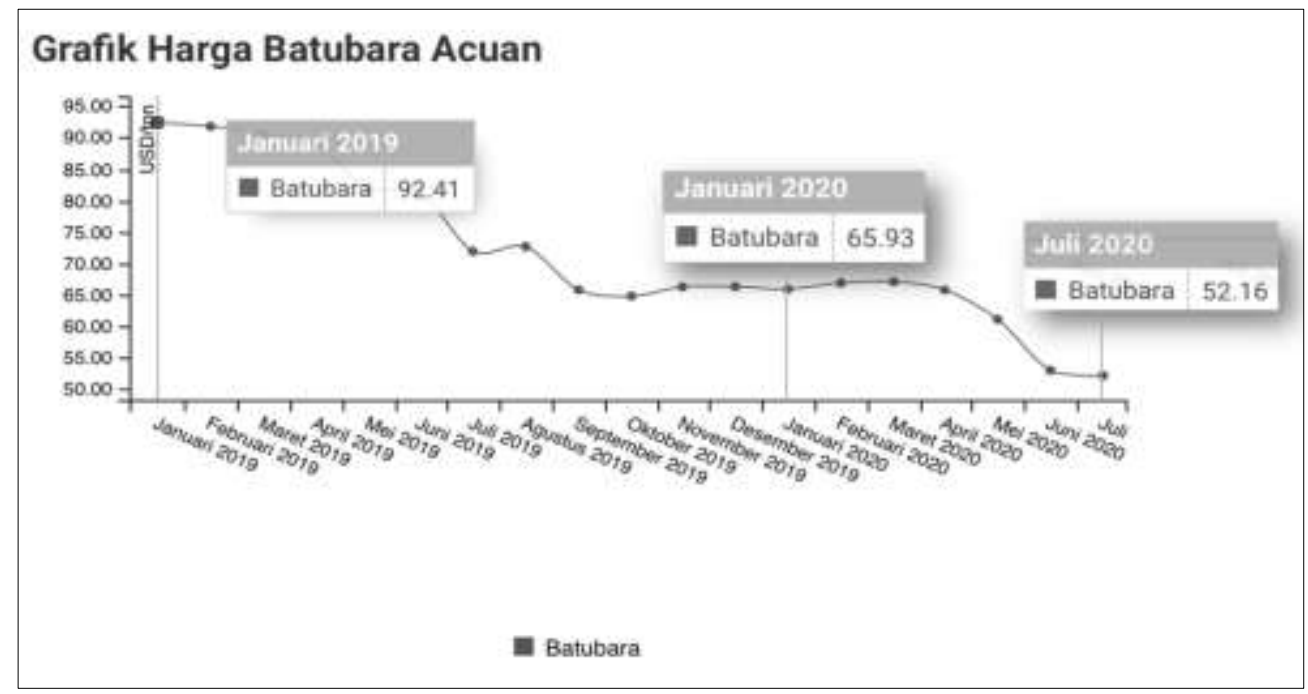

Gambar 2. Grafik Harga Batu Bara Acuan Bulan Januari 2019 - Juli 2020

Melemahnya harga jual batubara tentu berdampak langsung terhadap keberlangsungan dan performa perusahaan sehingga aspek biaya operasional harus lebih di optimalkan salah satunya adalah penggunaan bahan peledak

\section{- Optimalisasi Budget Powder Factor}

Rasio penggunaan bahan peledak yang di tetapkan untuk Pit South Pinang setiap tahunnya selalu terjadi trend penurunan dari tahun-tahun sebelumnya. Pit South Pinang sendiri mulai dioperasikan di tahun 2014 dengan di awali budget Powder Factor sebesar $0.320 \mathrm{~kg} / \mathrm{bcm}$ dan di tahun 2019 sebesar $0.220 \mathrm{~kg} / \mathrm{bcm}$ (dengan aktual Powder Factor $0.215 \mathrm{~kg} / \mathrm{bcm}$ ) Dengan kata lain telah terjadi penurunan budget sebesar $31 \%$ selama 6 tahun terakhir yang menyesuaikan terhadap perubahan karakteristik material dan juga perkembangan teknologi pada proses peledakan.

Untuk tahun 2020 telah di tetapkan budget Powder Factor untuk Pit South Pinang masih sebesar $0.220 \mathrm{~kg} / \mathrm{bcm}$ dimana hal ini tentu berdampak pada strategi optimalisasi penggunaan bahan peledak yang lebih efisien lagi daripada tahun sebelumnya 


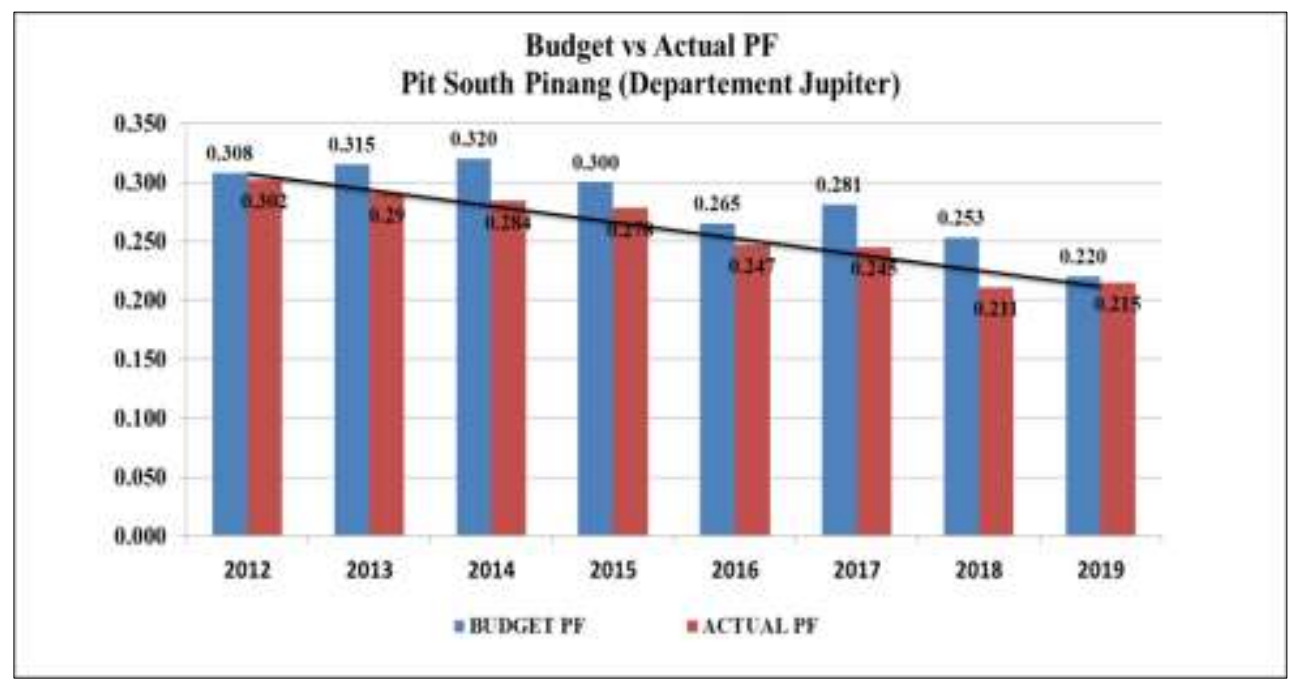

Gambar 3. Grafik Budget \& Aktual Powder Factor Pit Pinang South Tahun 2012 - 2019

\section{- Terbatasnya Kedalaman Lubang Drill}

Sejalan dengan penetapan budget rasio penggunaan bahan peledak (Powder Factor) di tahun 2020 di Pit South Pinang sebesar 0.220 $\mathrm{Kg} / \mathrm{bcm}$, maka kedalaman maksimal lubang drill yang bisa di bor adalah hanya sebatas kedalaman 7 - 7.5 meter dengan tingkat kelolosan fragmentasi P-30 secara teori sebesar $60-61 \%$ (batas minimal standar perhitungan Kuz-Ram saat ini). Kedalaman 7 - 7.5 meter tersebut tentu tidak di rekomendasikan untuk penggalian 2 phase digger jenis Liebherr R996B yang membutuhkan kedalaman optimal $9-10$ meter (pertimbangan tinggi penggalian ideal untuk tiap phase nya adalah sebesar $4-5$ meter)

Oleh karena itu di butuhkan suatu strategi baru untuk dapat menambah kedalaman lubang drill dengan menggunakan Bottom Air Deck (BAD) di dasar lubang ledak (dengan tanpa menambah penggunaan bahan peledak yang di gunakan)

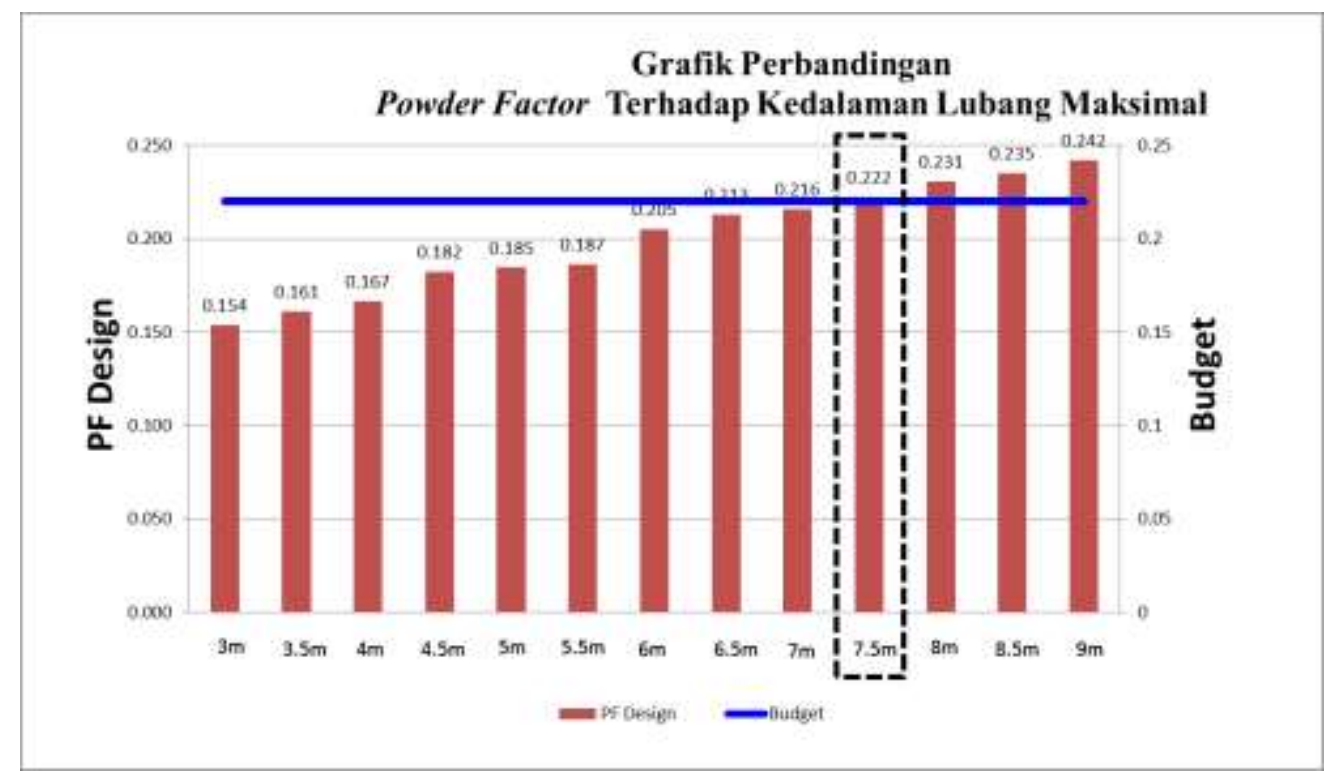

Gambar 4. Grafik Budget Powder Factor Terhadap Kedalaman Maksimal

- Perbedaan Karakteristik Material Tanah Penutup di Panel 3 \& 4
Penelitian ini dilakukan pada Panel 4 Pit South Pinang dimana berdasarkan observasi dilapangan terhadap karakteristik material di 
Panel 4 terlihat relatif lebih lunak di bandingkan dengan Panel 3. Material tanah penutup di Panel 4 umumnya tersusun atas material Mudstone dengan rata-rata UCS 3.7 Mpa sedangkan Panel 3 umum tersusun material Sandstone dan Siltstone dengan rata-rata UCS 4.5-4.9 Mpa.

Tabel 1. Rata-Rata UCS Panel 3 dan Panel 4 Pit South Pinang

\begin{tabular}{|c|l|c|}
\hline Panel & LITHOLOGY & UCS (Mpa) \\
\hline \multirow{2}{*}{ Panel 3} & Sandstone & 4.9 \\
\cline { 2 - 3 } & Siltstone & 4.5 \\
\hline Panel 4 & Mudstone & 3.7 \\
\hline
\end{tabular}

Selain dari aspek UCS dan lithology batuan, dari segi visual terhadap material cutting drill juga terlihat perbedaan yang sangat signifikan di antara Panel 4 dan Panel 3. Berbanding lurus dengan data rata-rata UCS di atas, cutting drill panel 4 umumnya lebih bersifat Soft - Medium (cutting drill berupa material pasiran basah bercampur dengan mudstone/claystone) dibandingkan terhadap Panel 3 yang lebih bersifat lebih keras.

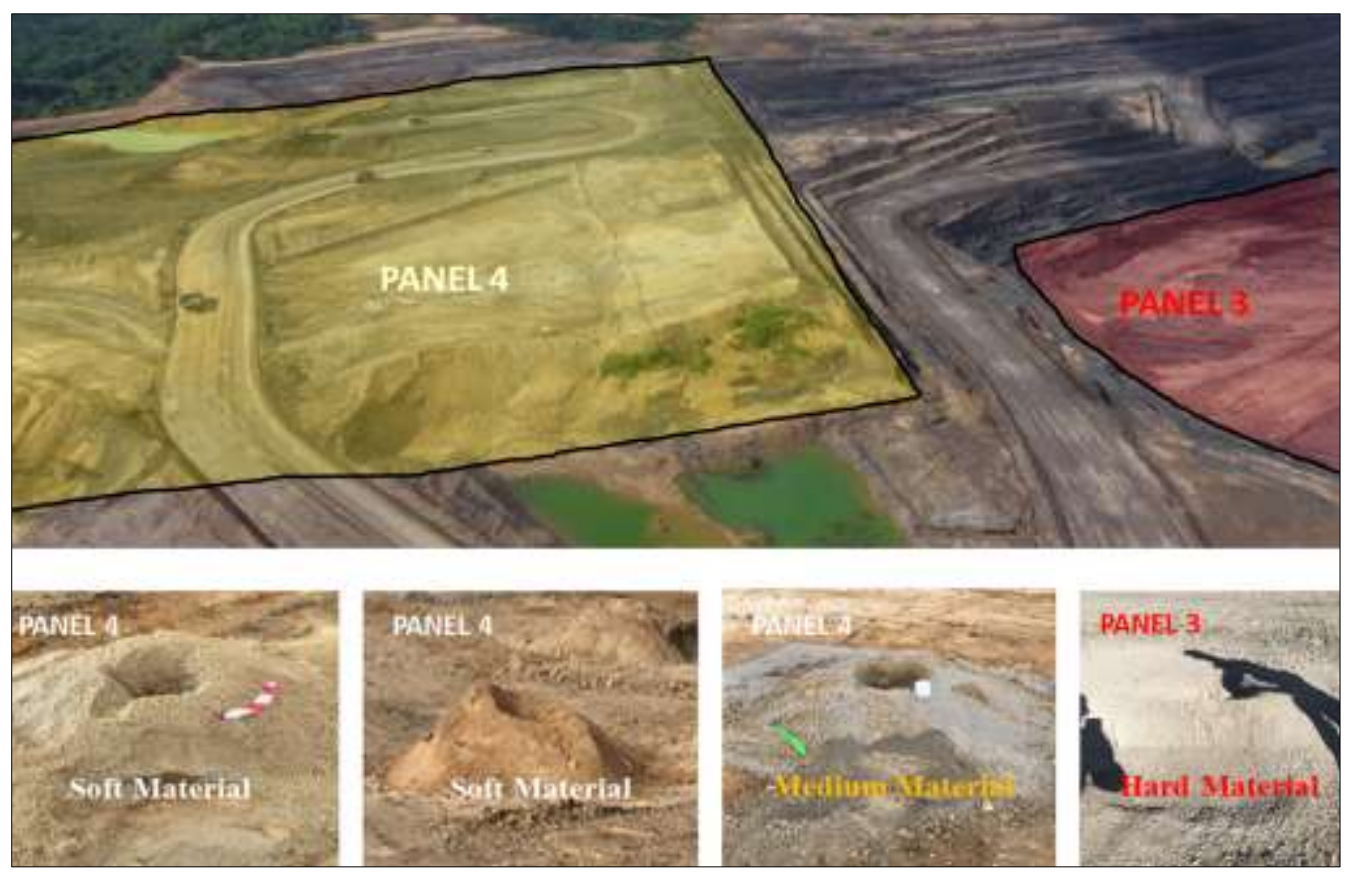

Gambar 5 . Perbedaan Karakteristik Cutting Drill Panel 3 \& Panel 4

Berdasarkan atas pertimbangan perbedaan karakteristik material yang sangat signifikan di atas, maka Panel 4 berpotensi lebih besar untuk dilakukan optimalisasi penggunaan bahan peledak melalui Project Expand Pattern (melalui pendekatan analisis Kuz-Ram dan Scale Depth Of Burrial). Sedangkan untuk panel 3 sendiri tidak di lakukan Trial Expand Pattern. Adapun beberapa point yang menjadi tujuan dari penelitian ini adalah sebagai berikut :

\section{METODOLOGI PENELITIAN}

Metode penelitian untuk menyelesaikan permasalahan dalam penelitian ini adalah dengan
- Menganalisa pengaruh implementasi Bottom Air Deck (BAD) terhadap Produktivitas digger, Fragmentasi hasil peledakan dan Powder Factor

- Menganalisa pengaruh implementasi Expand Pattern terhadap Produktivitas digger, Fragmentasi hasil peledakan dan Powder Factor

menggunakan pendekatan Dasar Teori/ Studi Literatur, Observasi \& Pengambilan Data Lapangan di lanjutkan dengan tahap Pengolahan Data yang kemudian dianalisis untuk menemukan solusi penyelesaian masalah. 


\section{- Teori Dasar Bottom Air Deck}

Bottom Air Deck merupakan istilah rongga udara yang terdapat di bagian bawah kolom bahan peledak yang berfungsi untuk membuat perangkap energi dan mengurangi energi terbuang secara vertikal. Rongga udara yang ada akan menyebabkan energi hasil peledakan lebih merata ke sekitar lubang ledak dan menciptakan Fragmentasi peledakan yang lebih seragam. Menurut Nurislam et al. (2016) membuat Air Deck pada lubang ledak berguna untuk menciptakan kurungan energi dan mengurangi pengeluaran gas secara vertikal.

Beberapa kajian yg pernah dilakukan terhadap efektivitas Air Decking antara lain :

- Mel'Nikov (1979)
Melakukan percobaan dan menyimpulkan bahwa Air Gap (ruang udara kosong) dalam lubang ledak bertindak sebagai energi akumulator.

- Marchhenko (1982)

Tekanan udara di kolom Air Gap memperbesar rekahan mikro yg sebelumnya sudah dihasilkan gelombang kejut utama saat peledakan.

- Pompanna \& Chikkareddy (1993)

Menyimpulkan hasil kajiannya bahwa penggunaan udara/Air Gap ini dapat menurunkan Ground vibration dan Backbreak.

- Jhanwar (1996)

Menyimpulkan mekanisme ini dapat mengurangi pemakaian bahan peledak 25$30 \%$.

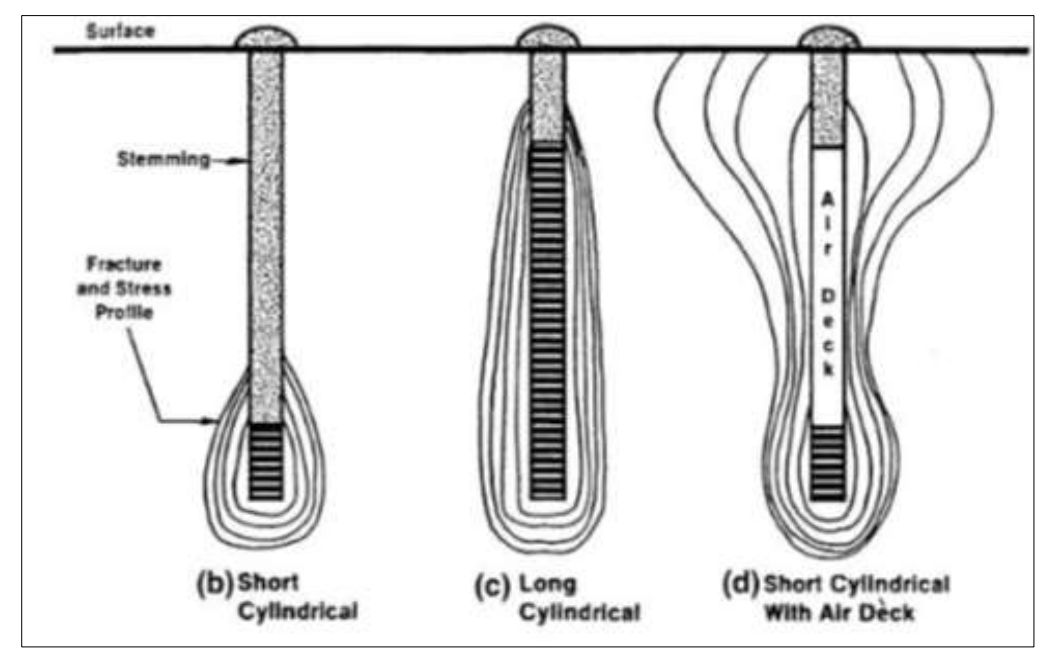

Gambar 6. Tekanan yang Dihasilkan dari Kolom Isian Air Deck dan Non Air Deck (F. Chiapetta and Memmele, 1987)

Untuk dapat mengimplementasikan Bottom Air Deck pada proyek penelitian ini maka PT. Kaltim Prima Coal melalui Departement Drill \& Blast telah melakukan kerja sama dengan PT. Empat Enam Jaya Abadi dalam hal penyediaan Produk Sysdeck yang di fungsikan sebagai Bottom Air Deck pada lubang ledak.
Sysdeck sendiri merupakan piranti berupa mangkok fleksibel berbentuk kerucut yang di sangga oleh stand berupa pipa PVC dengan panjang 1 meter yang di pasang pada posisi dasar dari lubang ledak dan dapat menahan beban seberat $+/-300 \mathrm{~kg}$ 

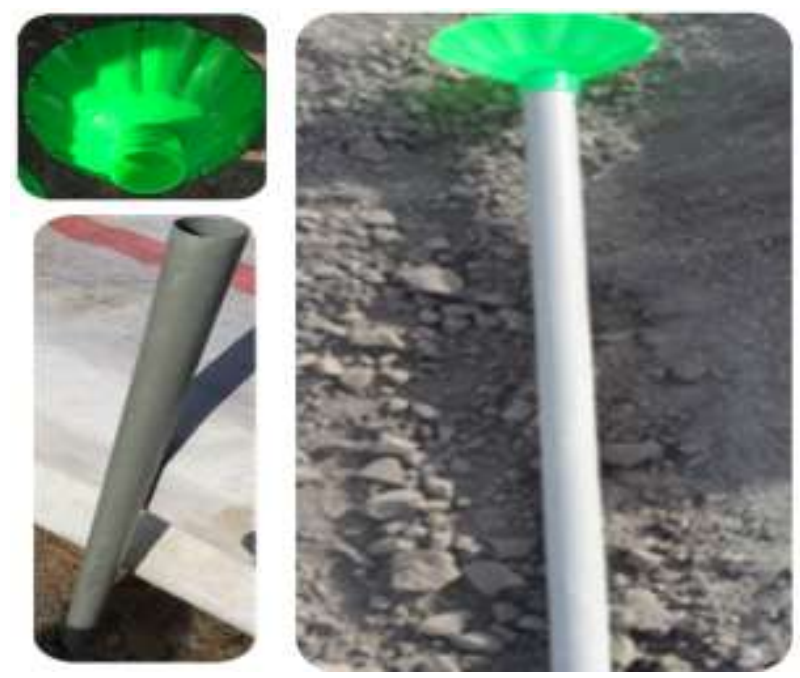

Gambar 7. Produk Sysdeck Sebagai Bottom Air Deck (BAD) di Pit South Pinang Panel 3 \& 4

- Hubungan Rock Mass Rating, Air Deck Factor \& Air Deck Length

Pada penerapan Bottom Air Deck, panjang kolom Air Deck dalam hal ini di sebut sebagai Air Deck Length (ADL) merupakan parameter yang paling krusial. ADL yang diterapkan berbeda-beda sesuai massa batuan sekitar area peledakan. Faktor yang mempengaruhi ADL adalah nilai Rock Mass Rating (RMR).

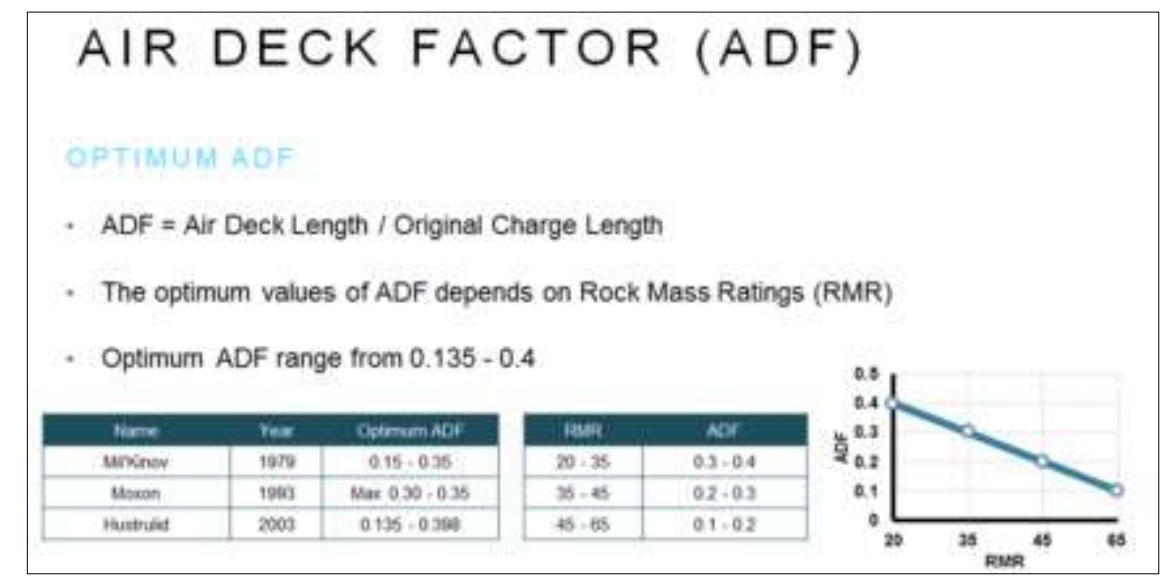

Gambar 8. Hubungan Antara Rock Mass Rating, Air Deck Factor \& Air Deck Length (Mel Nikov, 1979)

Rock Mass Rating (RMR) merupakan suatu metode klasifikasi massa batuan dengan melakukan pembobotan terhadap 5 parameter utama \& 4 parameter pendukung, yaitu :

- Kuat tekan uniaksial batuan utuh (UCS)

- Rock Quality Designation (RQD)

- Spasi Bidang Diskontinu

- Kondisi Bidang Diskontinu (4 sub point)

- Kondisi Air Tanah
Bobot-bobot dari setiap parameter nantinya akan dijumlahkan untuk memperoleh bobot total massa batuan. Berdasarkan pengamatan dan pengambilan data di lapangan yang sudah di lakukan, bobot. Rock Mass Rating (RMR) untuk Pit South Pinang Panel 3 \& 4 berada pada nilai 38 sehingga nilai Air Deck Factor (ADF) yang optimal berada pada kisaran 0.2 0.3 


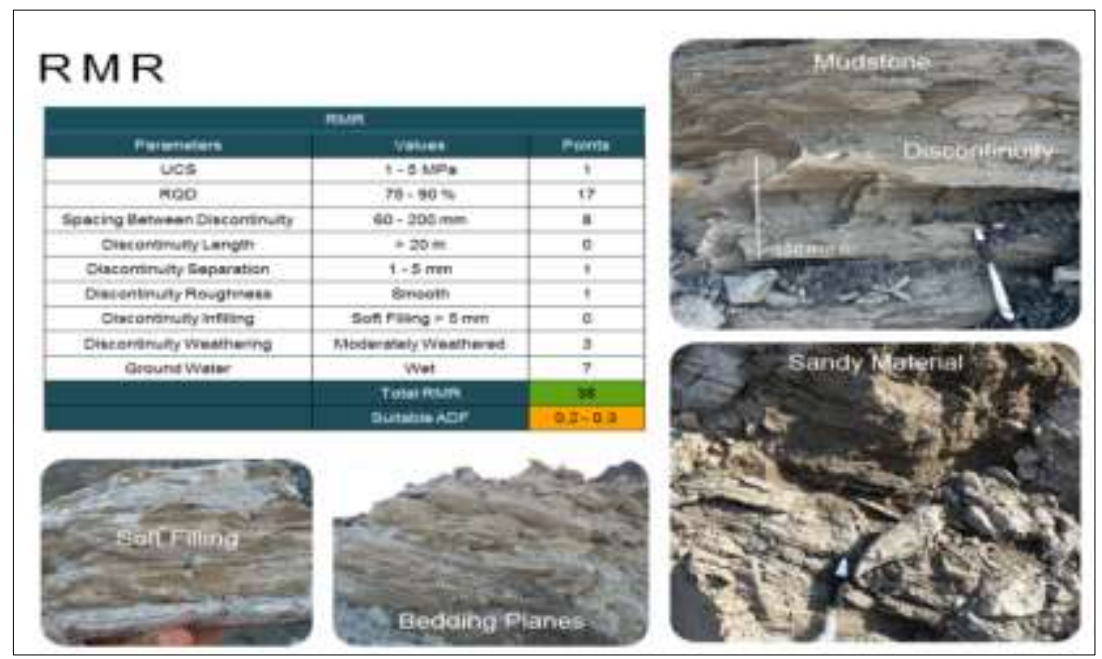

Gambar 9. Rock Mass Rating (RMR) Pit South Pinang

Setelah penentuan nilai RMR dan ADF, langkah selanjutnya adalah menentukan Air Deck Length (ADL) yang optimal dengan menggunakan persamaan sebagai berikut (Mel Nikov, 1979) :

$A D L=A D F \quad x \quad O C C$
Dimana :

ADF : Air Deck Factor

ADL : Air Deck Length (m)

OCC : Original Charge Column Length $(m)$

Tabel 2. Air Deck Length (ADL) optimum di Pit South Pinang

\begin{tabular}{|r|r|r|c|r|r|r|}
\hline \multicolumn{7}{|c|}{ ADL Optimum Pit South Pinang } \\
\hline No & Depth (m) & OCC (m) & ADF Min. & ADF Maks. & ADL Min. & ADL Maks. \\
\hline 1 & 3.0 & 0.9 & 0.2 & 0.3 & 0.2 & 0.3 \\
\hline 2 & 4.0 & 1.3 & 0.2 & 0.3 & 0.3 & 0.4 \\
\hline 3 & 5.0 & 1.8 & 0.2 & 0.3 & 0.4 & 0.5 \\
\hline 4 & 6.0 & 2.4 & 0.2 & 0.3 & 0.5 & 0.7 \\
\hline 5 & 7.0 & 3.0 & 0.2 & 0.3 & 0.6 & 0.9 \\
\hline 6 & 8.0 & 3.6 & 0.2 & 0.3 & 0.7 & 1.1 \\
\hline 7 & 9.0 & 4.3 & 0.2 & 0.3 & 0.9 & 1.3 \\
\hline
\end{tabular}

Dari simulasi perhitungan di atas, terlihat bahwa nilai Air Deck Length (ADL) yang optimal dan bisa di implementasikan di Pit South Pinang berada pada kisaran panjang 0.7 - 1.3 meter untuk kedalaman lubang ledak rata-rata 8 - 9 meter. Dalam kasus penelitian ini, untuk memudahkan dalam operasional lapangan, maka panjang ADL (kolom udara) yang di gunakan adalah 1 meter dengan menggunakan produk Sysdek. 


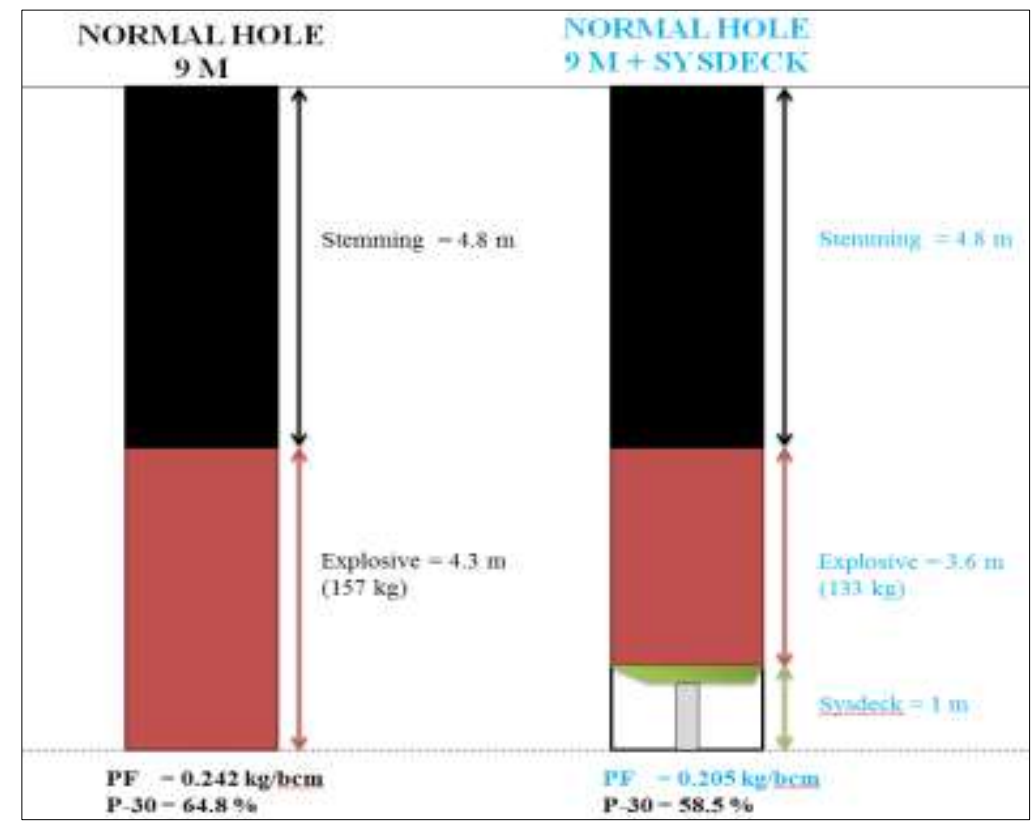

Gambar 10. Simulasi Penggunaan Sysdeck sebagai Bottom Air Deck (BAD) Pada Lubang Ledak 9 meter

Dari simulasi di atas dapat dilihat bahwa dengan implementasi Bottom Air Deck (BAD) pada lubang ledak 9 meter, di peroleh potensi penghematan rasio penggunaan bahan peledak (Powder Factor) sebesar 15\% dibandingkan dengan lubang Normal tanpa BAD

\section{- Analisa Kuz-Ram}

Analisa Kuz-ram digunakan sebagai pendekatan matematis untuk mendapatkan tingkat keseragaman batuan hasil peledakan (persentase kelolosan batuan dengan ukuran $\leq 30 \mathrm{~cm}$ minimal 60\%). Pada analisa ini didetailkan 3 parameter utama yaitu :

1. Parameter Batuan

Analisa terhadap Densitas, Hardness,

Specific Gravity Influence (SGI), Rock

Mass (RMD), Joint Plane Spacing (JPS)

dan Joint Plane Orientation (JPO)

2. Parameter Bahan Peledak
Analisa terhadap Relatif Weight Strength (RWS), Densitas ANFO \& Emulsi dan Coloumn Charges

3. Parameter Geometri Pemboran Analisa terhadap Burden, Spasi, Diameter Lubang, Sub Drill, Kedalaman Lubang dan Pola Pemboran

Departement Drill \& Blast melalui proyek penelitian sebelumnya sudah menetapkan distribusi fragmentasi P-30 teoritis sebesar minimal $60 \%$ (untuk mendapatkan P-30 secara aktual sebesar $\geq 80 \%$ ). Dalam penelitian ini dilakukan trial P-30 teoritis pada range $62 \%$ $65 \%$ dengan tetap mempertahankan Distribusi Fragmentasi aktual P-30 di lapangan sebesar $\geq 80 \%$. Dengan adanya implementasi Bottom Air Deck \& Expand Pattern pada lubang ledak, maka akan terjadi optimalisasi bahan peledak sebesar $15 \%$ sehingga ikut berpengaruh pada hasil akhir perhitungan Kuz-Ram. 
Fragmentation P-30 After Expand Pattern

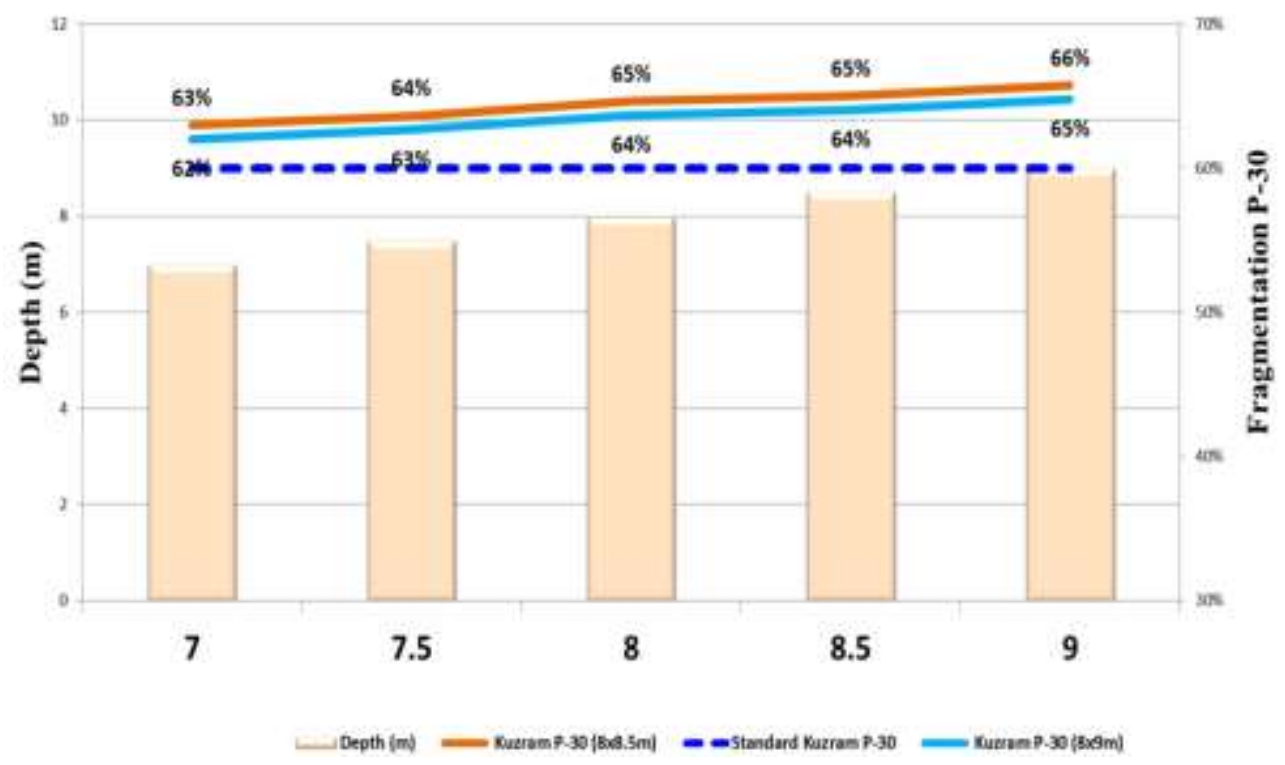

Gambar 11. Distribusi Fragmentasi P-30 Dengan Implementasi Bottom Air Deck

- Analisa Scale Depth Of Burial (S.D.O.B)

Pengukuran empiris dari energi pengurungan peledakan dinyatakan sebagai Scaled Depth of Burial (SD). Scaled Depth sendiri dapat didefinisikan sebagai rasio panjang material stemming terhadap jumlah bahan peledak pada ruang yang setara dengan 10 diameter lubang ledak.

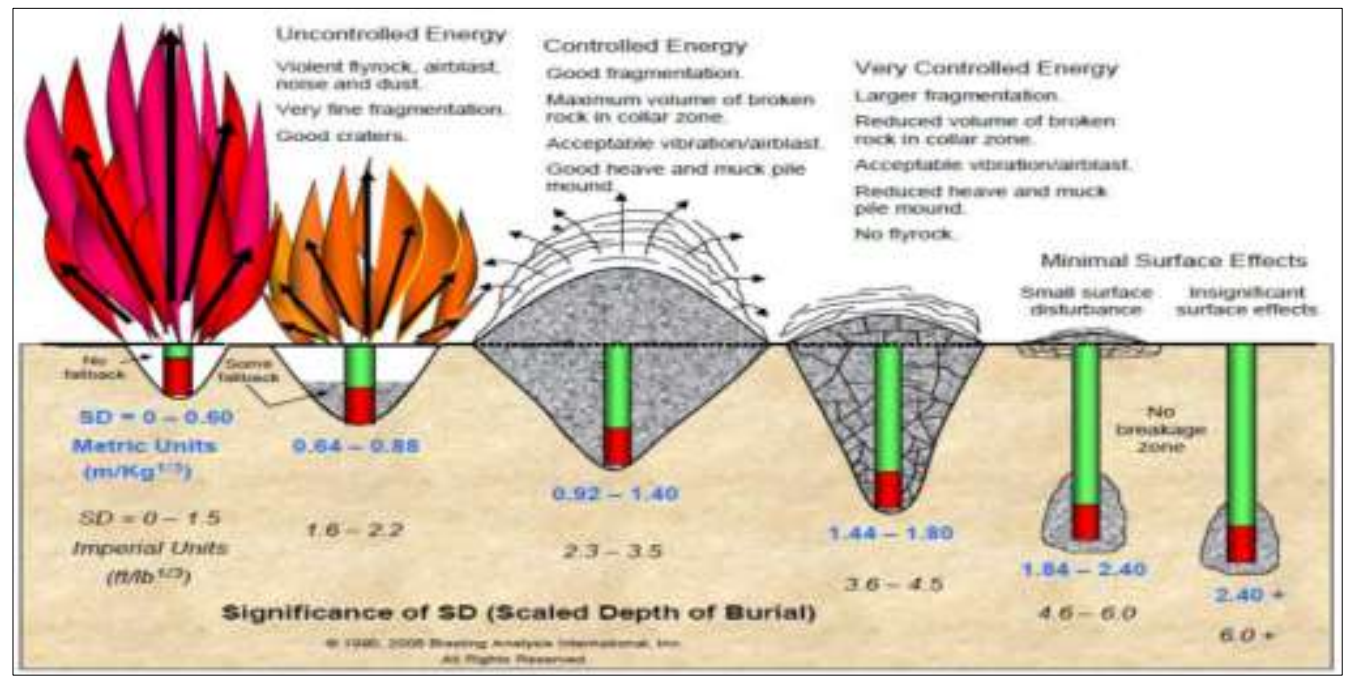

Gambar 12. Scaled Depth Of Burial (S.D.O.B)

Seperti yang terlihat pada gambar di atas, apabila panjang stemming tidak memadai (rasio SD-nya rendah) maka energi yang dilepaskan akan tidak terkontrol, sebagian besar energi peledakan akan menghasilkan gangguan berupa Fly rock dan Air blast. Sebagian kecil energinya akan merambat untuk menghancurkan batuan. Namun demikian, apabila stemming terlalu panjang (rasio SD-nya tinggi), maka energy peledakan akan tersumbat dan menghasilkan material oversize/ boulder dan cost perbaikan terkait. 


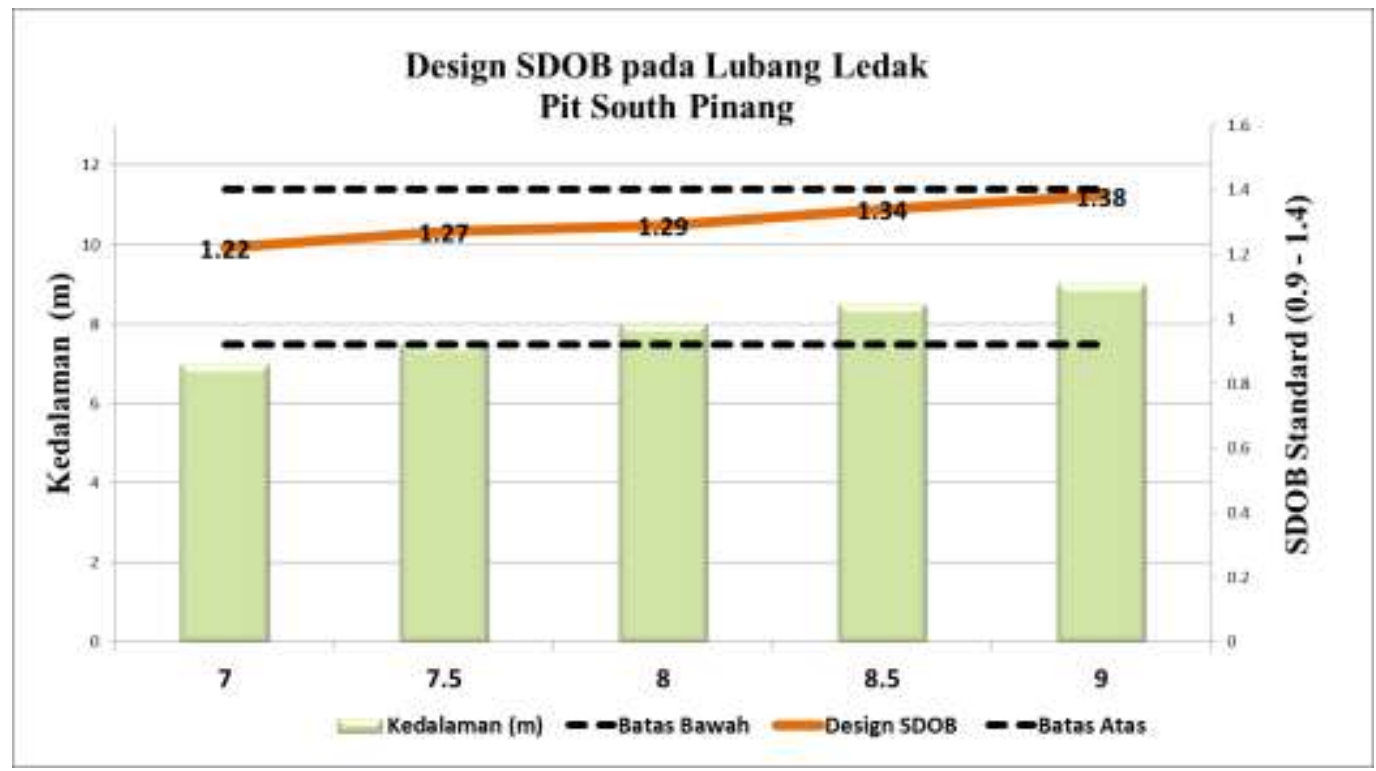

Gambar 13. Scaled Depth Of Burial (S.D.O.B)

Dalam penelitian ini, ditetapkan rasio SD yang optimal pada kisaran angka $0.92-1.40 \mathrm{~m} / \mathrm{kg}^{1 / 3}$

\section{HASIL DAN PEMBAHASAN}

Setelah dilakukan implementasi Bottom Air Deck (BAD) dan Trial Expand Pattern (8x8.5 menjadi 8x9 m) pada setiap rencana lokasi peledakan selama untuk mendapatkan kualitas hasil peledakan yang tetap optimal

bulan Januari - September 2020 di Pit South Pinang Panel 3 \& 4, maka tolak ukur keberhasilan proyek ini dapat di lihat dari beberapa aspek parameter sebagai berikut ini :

- Powder Factor (PF)

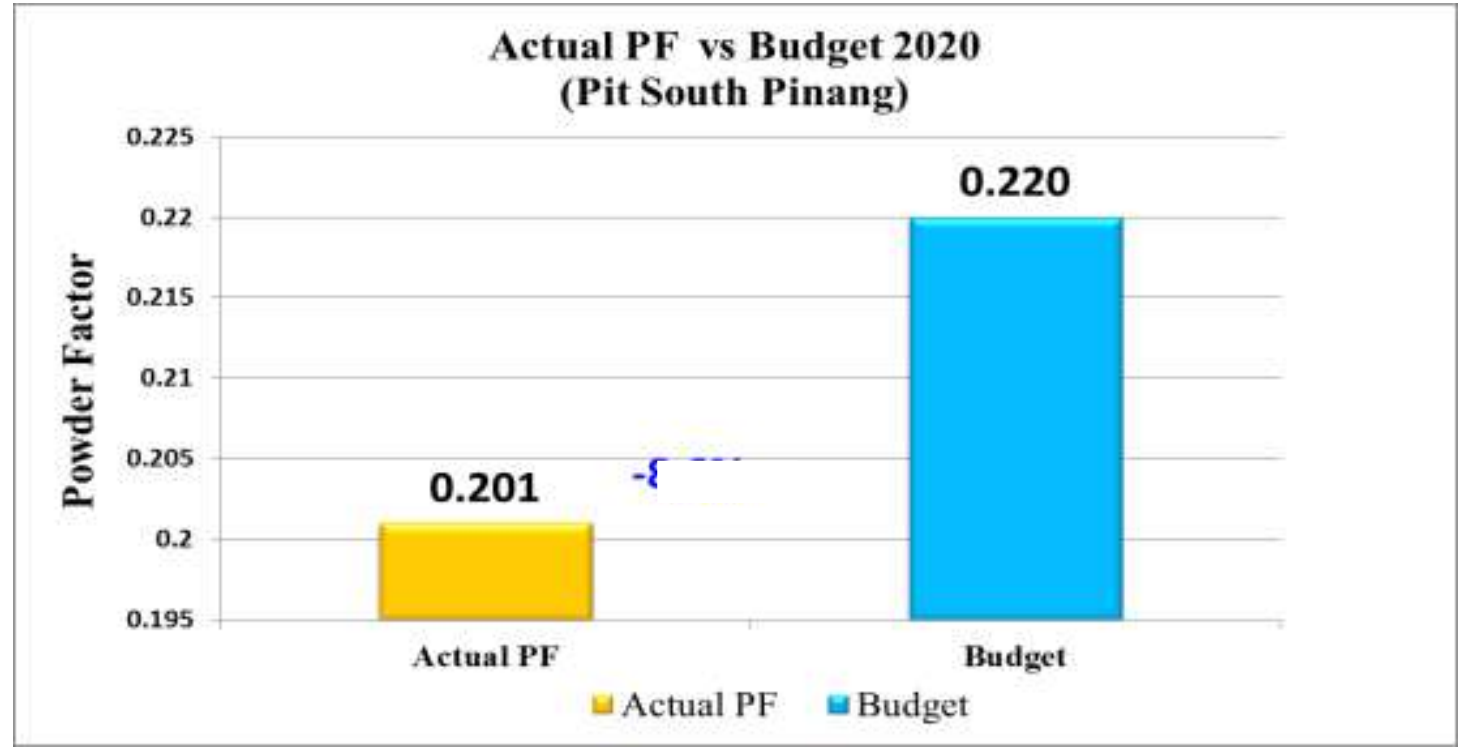

Gambar 14. Aktual Powder Factor Bulan Januari - September 2020

Di Pit South Pinang

Dari segi rasio penggunaan bahan peledak (PF) selama bulan Januari - September 2020, Powder Factor dapat di optimalkan sebesar
$8.6 \%$ dari budget yang telah di tetapkan dimana aktual PF $=0.201 \mathrm{~kg} / \mathrm{bcm}$ terhadap budget yang telah di tetapkan sebesar 0.220 
$\mathrm{kg} / \mathrm{bcm}$. Optimalisasi tersebut setara dengan penghematan bahan peledak $240.160 \mathrm{~kg}$ dengan tanpa mengorbankan kualitas hasil peledakan

- Produktivitas Alat Gali-Muat

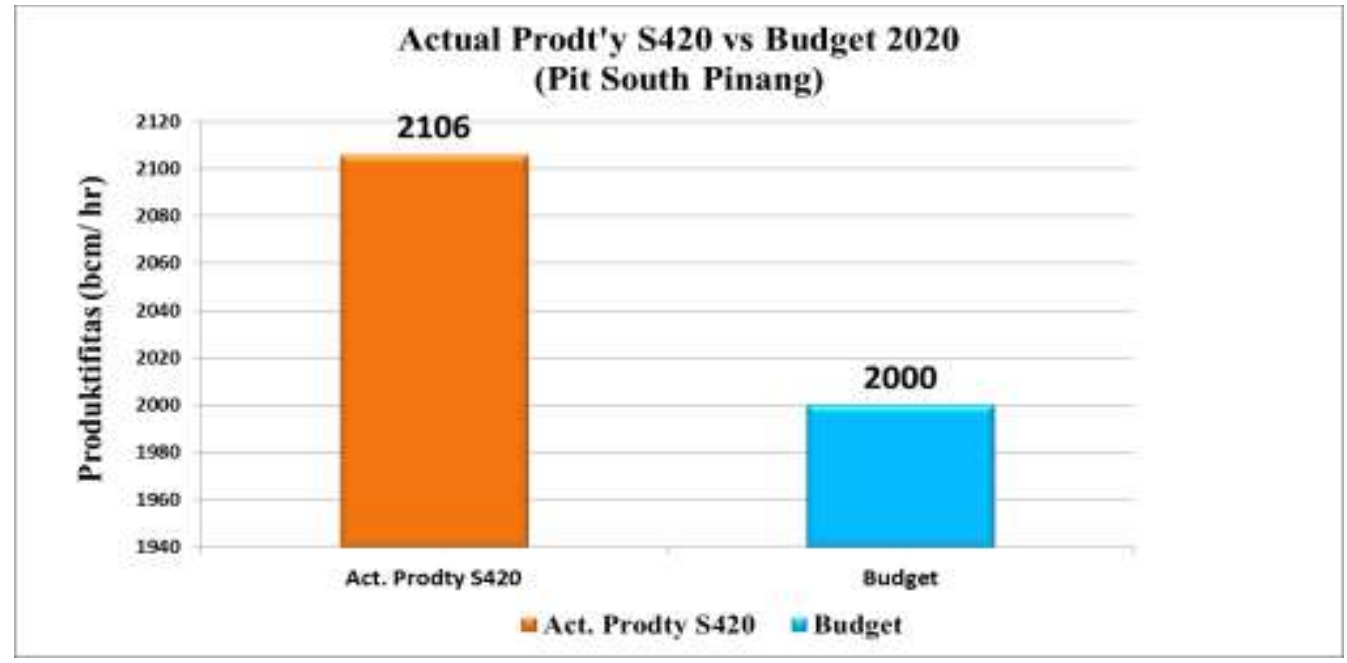

Gambar 15. Aktual Produktivitas Liebherr S420 Bulan Januari - September 2020

Dari gambar di atas terlihat aktual produktivitas Liebherr S420 selama bulan Januari - September 2020 yang beroperasi di Pit South Pinang panel 4 masih produktif di atas budget yang di tetapkan. Adapun Aktual produktivitas S420 sebesar 2,106 $\mathrm{bcm} / \mathrm{jam}$ atau $5.3 \%$ di atas budget $2,100 \mathrm{bcm} / \mathrm{jam}$.

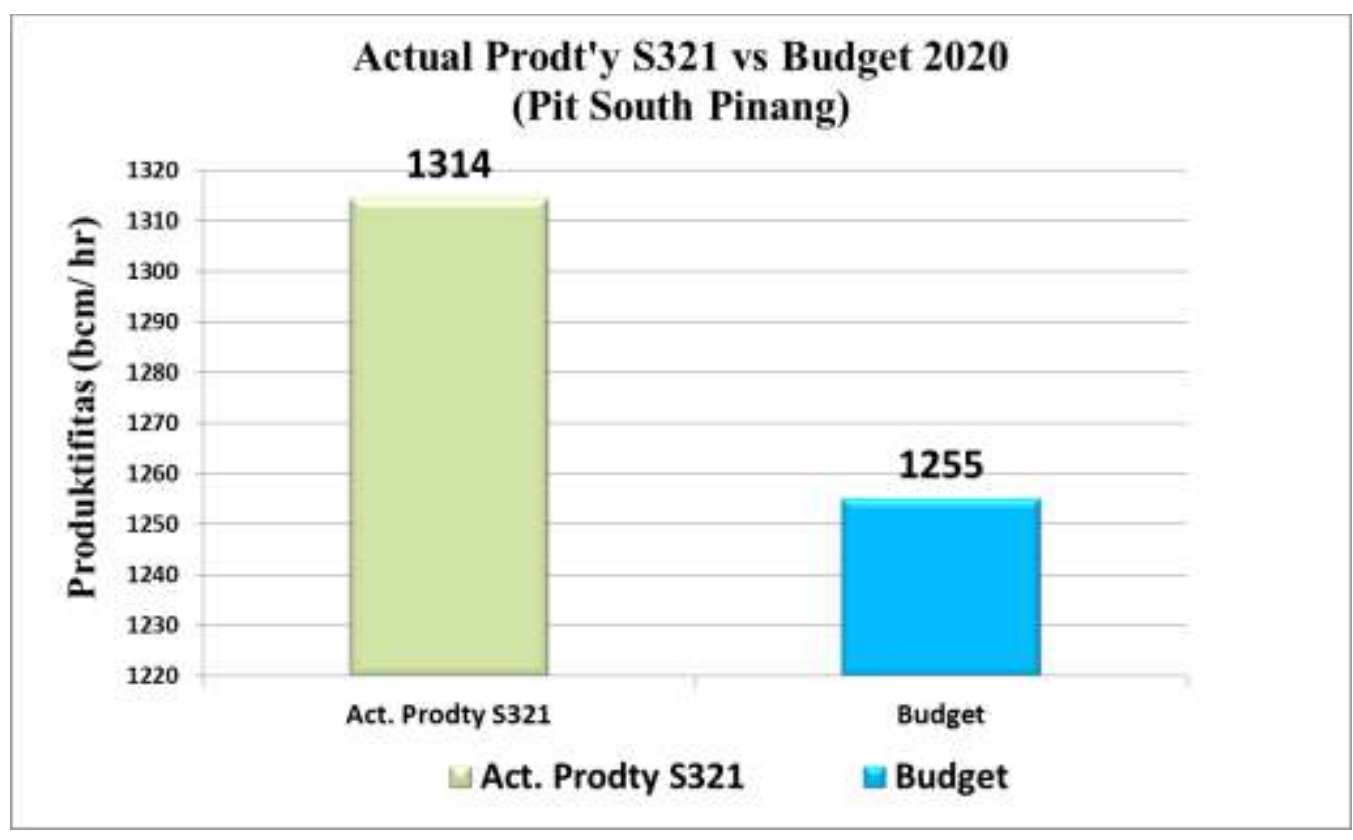

Gambar 16. Aktual Produktivitas Hitachi S321 Bulan Januari - September 2020

Adapun aktual produktivitas untuk Hitachi S321 selama bulan Januari - September 2020 yang beroperasi di Pit South Pinang panel 3 \& 4 terlihat juga masih produktif di atas budget yang di tetapkan. Adapun Aktual produktivitas
S321 sebesar $1,314 \mathrm{bcm} /$ jam atau $4.7 \% \mathrm{di}$ atas budget $1,255 \mathrm{bcm} / \mathrm{jam}$.

Dari segi produktivitas alat gali muat, terlihat bahwa implementasi Bottom Air Deck (BAD) dan Proyek Expand Pattern di Pit South 
Pinang tidak berdampak pada penurunan produktivitas aktual di lapangan.

- Aktual Distribusi Fragmentasi P-30

Keberhasilan proyek ini selain di lihat dari tolak ukur Powder Factor (PF) dan Produktivitas

Alat Gali-Muat, parameter aktual Distribusi Fragmentasi P-30 haruslah tetap berada di atas $80 \%$ (nantinya berkaitan erat dengan fill factor bucket alat gali - muat yang beroperasi). Selama proyek di lakukan, observasi dan pengambilan data Distribusi fragmentasi aktual sudah di lakukan dengan bantuan Software WipFrag untuk menganalisa ukuran fragment rata-rata terhadap material hasil peledakan.
Analisa fragmentasi ini dilakukan pada 2 lokasi peledakan dengan hasil sebagai berikut :

1. Lokasi PN48 (phase 1) : aktual Distribusi Fragmentasi P-30 $=88.08 \%$

2. Lokasi PN48 (phase 1) : aktual Distribusi Fragmentasi P-30 $=88.74 \%$

3. Lokasi PN48 (phase 2) : aktual Distribusi Fragmentasi P-30 $=89.03 \%$

4. Lokasi PN44 (phase 2) : aktual Distribusi Fragmentasi P-30 $=85.97 \%$

Dengan melakukan Implementasi $B A D$ dan trial Expand pattern (Distribusi P-30 secara teoritis Kuz-Ram pada range $62-65 \%$ ), maka hal ini tidak berdampak pada penurunan aktual Distribusi Fragmentasi P-30 pada setiap kualitas hasil peledakan. Aktual Distribusi fragmentasi P-30 tetap optimal berada di atas angka $80 \%$ sesuai dengan ketetapan saat ini.
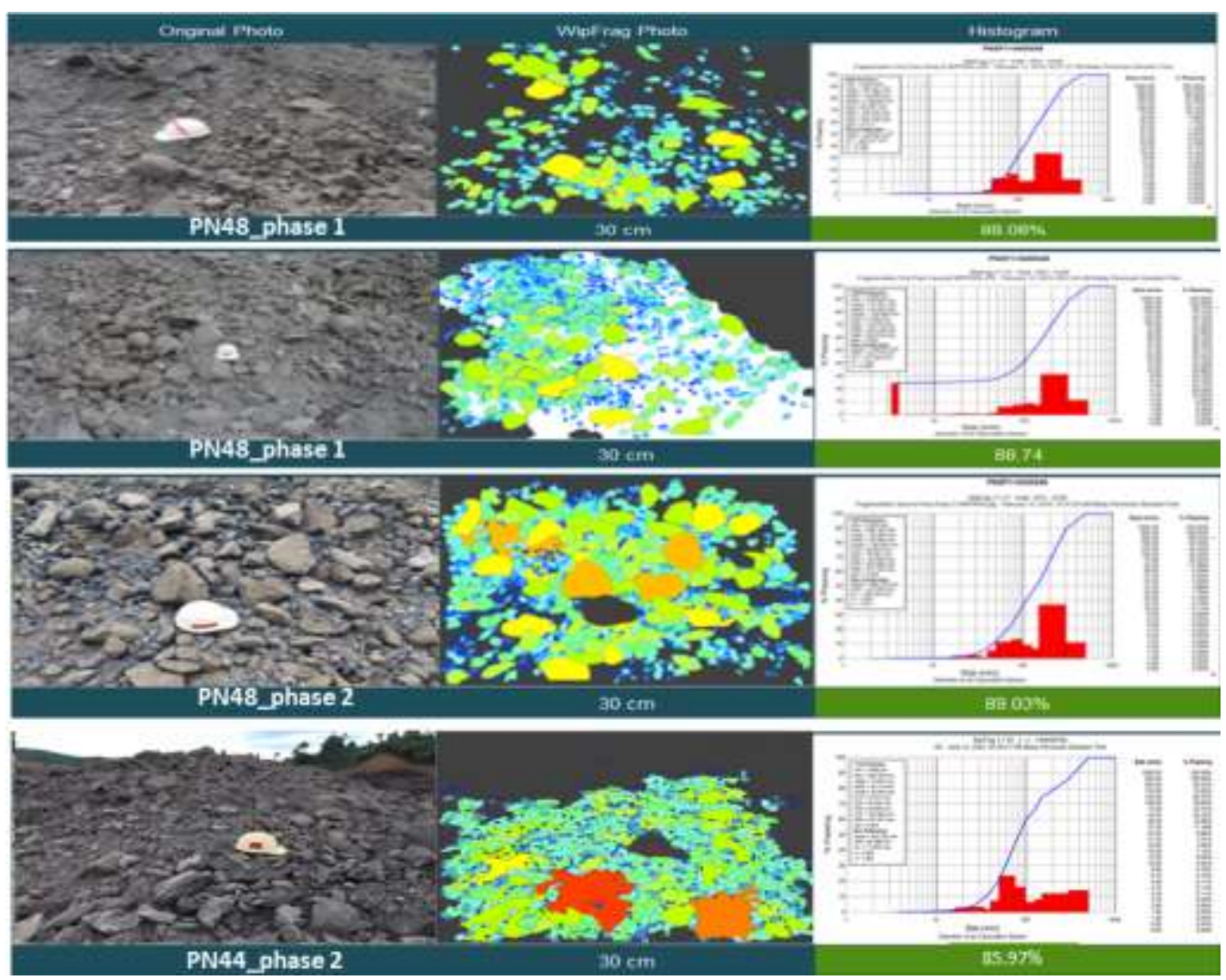

Gambar 17. Aktual Distribusi Fragmentasi P-30 Lokasi Penelitian

- Analisa Nett Cost Saving

Tahap akhir pada penelitian ini adalah perhitungan Nett Cost Saving terhadap proyek yang sudah di lakukan. Selama bulan Januari - September 2020 penggunaan bahan peledak telah berhasil di hemat sebanyak $240.160 \mathrm{~kg}$ atau setara dengan penghematan biaya peledakan sebesar $\$ 128,005$. Namun dalam perjalanan proyek ini, di perlukan biaya tambahan terhadap penggunaan Sysdeck sebagai Bottom Air Deck dan Services - Fixed Monthly Fee sebesar $\$ 43,118$ sehingga total Nett Saving Cost project ini adalah sebesar $\$ 84,888$ atau Rp.1,2 Milyar 


\begin{tabular}{|c|c|c|c|}
\hline \multicolumn{4}{|c|}{ Calculation Cost Saving } \\
\hline Actual OB Blasted & & $12,640,000$ & $\mathrm{bcm}$ \\
\hline \multicolumn{2}{|l|}{ PF After Optimization } & 0.201 & kg/bcm \\
\hline \multicolumn{2}{|l|}{ Actual Explosive PF0.201 } & $2,540,640$ & KG \\
\hline \multirow{2}{*}{\multicolumn{2}{|c|}{$\begin{array}{l}\text { PF Budget } \\
\text { Actual Explosive PF0.220 }\end{array}$}} & 0.220 & $\mathbf{k g} / \mathbf{b c m}$ \\
\hline & & $2,780,800$ & $\mathrm{~kg}$ \\
\hline \multirow{2}{*}{$\begin{array}{l}\text { Cost Saving Explosive } \\
\text { Bottom Air Deck Cost }\end{array}$} & $\$$ & & 128,005 \\
\hline & $\$$ & & 43,118 \\
\hline \multirow{2}{*}{ Nett Cost Saving } & $\$$ & & $\mathbf{8 4 , 8 8 8}$ \\
\hline & $\mathbf{R p}$ & 1,230 & $, 871,554$ \\
\hline
\end{tabular}

Gambar 18. Perhitungan Nett Cost Saving Project Penelitian

\section{KESIMPULAN}

Secara keseluruhan, hasil yang didapat selama proyek dilakukan antara lain sebagai berikut :

1. Implementasi Bottom Air Deck dan Trial Expand Pattern telah memberikan kontribusi positif terhadap Optimalisasi Powder Factor yang lebih optimal sebesar $8.6 \%$ terhadap budget 2020

2. Selama proyek berjalan, terbukti tidak mengorbankan produktivitas alat gali-muat dimana Produktivitas Liebherr S420 dan Hitachi S321 masing-masing masih produktif sebesar $5.3 \%$ dan $4.7 \%$ terhadap budget yang sudah di tetapkan

\section{DAFTAR PUSTAKA}

Cunningham, C.V.B. 1983. The Kuz-Ram model for prediction of fragmentation from blasting. In $\mathrm{R}$. Holmberg \& A Rustan (eds), Proceedings of First

Mel'nikov, N.V., and Marchenko, L.N., 1971, Effective Methods of Application of Explosion Energy in Mining and Construction, 12th U.S Symposium Dynamic Rock Mechanics, chap. 18, pp35-378, New York, AIME.

Moxon, N.T., and Mead D. Richardson, S.B., 1991, Reducing Blasting Costs Using Air-Decks The Do's and Don'ts, Newcastle Laboratories Newcastle, NSW , Australia.

Jhanwar, J.C., (2011). Theory and Practice of Air-Deck Blasting in Mines and Surface Excavations: A Review. Geotech Geol Eng, 29:651-663

Harga Jual Batubara (HBA), data diperoleh melalui situs internet

https://www.minerba.esdm.go.id/harga_acuan.

Diunduh pada tanggal 22 Oktober 2020

Budget_D\&B_MOD_2020_PF 0.246_Pass4
3. Dari segi aktual Distribusi Fragmentasi P-30 dilapangan masih terjaga baik dan tetap optimal sesuai dengan ketetapan saat ini dimana aktual P-30 berkisar antara 85\% $89 \%$ (ketetapan minimal P-30 $=80 \%$ )

4. Total penghematan penggunaan bahan peledak hingga sampai akhir bulan September 2020 adalah sebesar $240.160 \mathrm{~kg}$ atau setara dengan Nett Cost Saving sebesar $\$ 84,888$ atau Rp.1,2 Milyar

Atas pencapaian ini, terbukti bahwa Implementasi Bottom Air Deck dan Trial Expand Pattern secara terintegrasi dan terukur telah memberikan perbaikan terhadap hasil peledakan yang merupakan dampak positif dari kemajuan teknologi terhadap dunia pertambangan khususnya di bidang peledakan.

Budget Plan_2020_Nov OL 2019_v2.1

AdHoc Production Statistics_Mine Optimization Departement_July 2005, Minvu Launcher 